\title{
Assessment of Physicochemical and Thermal Properties of Energy of Consciousness Healing Treated Ferrous Sulphate Using PXRD, PSD, DSC, and TGA/DTG Analysis
}

\author{
Alice Branton $^{1}$, Snehasis Jana ${ }^{2, *}$ \\ ${ }^{1}$ Trivedi Global, Inc., Henderson, Nevada, USA \\ ${ }^{2}$ Trivedi Science Research Laboratory Private Limited, Bhopal, Madhya Pradesh, India
}

Email address:

publication@trivedieffect.com (S. Jana)

*Corresponding author

\section{To cite this article:}

Alice Branton, Snehasis Jana. Assessment of Physicochemical and Thermal Properties of Energy of Consciousness Healing Treated Ferrous Sulphate Using PXRD, PSD, DSC, and TGA/DTG Analysis. Modern Chemistry. Vol. 5, No. 4, 2017, pp. 50-59. doi: $10.11648 /$ j.mc.20170504.11

Received: May 20, 2017; Accepted: June 6, 2017; Published: July 14, 2017

\begin{abstract}
Ferrous sulphate is an inorganic salt of iron used to treat iron deficiency anaemia and maintain the overall health in our body. The current study was designed to evaluate the impact of The Trivedi Effect ${ }^{\mathbb{B}}$-Energy of Consciousness Healing Treatment on the physicochemical and thermal properties of ferrous sulphate using PXRD, PSA, DSC, and TGA/DTG analysis. Ferrous sulphate test item was divided into two parts, one part was considered as control (without Biofield Energy Treatment), whereas the second part received The Trivedi Effect ${ }^{\mathbb{B}}$-Biofield Energy Treatment remotely by the renowned Biofield Energy Healer, Alice Branton. The PXRD data revealed that the relative intensities and crystallite size of the characteristic diffraction peaks in the treated sample were significantly altered from $-26.74 \%$ to $421.23 \%$ and from $-24.93 \%$ to $42.91 \%$, respectively compared with the control sample. The average crystallite size of the treated sample was significantly increased by $6.39 \%$ compared to the control sample. The particle size values at $\mathrm{d}_{10}, \mathrm{~d}_{50}, \mathrm{~d}_{90}$ and $\mathrm{D}(4,3)$ values were significantly increased by $30.43 \%, 35.94 \%, 19.49 \%$, and $26.26 \%$, respectively and the surface area was significantly decreased by $53.26 \%$ compared with the control sample. The melting temperature of the treated sample in the $1^{\text {st }}$ and $3^{\text {rd }}$ peaks was increased by $1.61 \%$ and $1.04 \%$ respectively, whereas decreased by $5.71 \%$ and $1.04 \%$ in the $2^{\text {nd }}$ and $4^{\text {th }}$ peaks, respectively compared with the control sample. Consequently, the total latent heat of fusion to transition from $\mathrm{FeSO}_{4} \cdot 7 \mathrm{H}_{2} \mathrm{O}$ to $\mathrm{FeSO}_{4}$ was decreased by $0.44 \%$ in the treated sample compared with the control sample. The TGA thermograms of both the samples exhibited four steps of thermal degradation. The total weight loss in the treated sample was increased by $0.62 \%$ compared with the control sample. The maximum thermal decomposition temperature $\left(\mathrm{T}_{\max }\right)$ of treated sample was increased by $5.81 \%$ and $0.26 \%$ in the $1^{\text {st }}$ and $4^{\text {th }}$ peak respectively, but the $T_{\max }$ of $2^{\text {nd }}$ and $3^{\text {rd }}$ peaks were decreased by $2.58 \%$ and $2.38 \%$, respectively compared to the control sample. Overall, DSC and TGA/DTG of the treated sample showed that the thermal stability was changed compared with the control sample. The Trivedi Effect ${ }^{\mathbb{B}}$-Consciousness Energy Healing Treatment might lead to the production of a polymorphic form of ferrous sulphate, which would have better powder flowability and appearance with altered thermal stability compared to the control sample. Alice's Biofield Energy Treated ferrous sulphate would be useful to design better nutraceutical/pharmaceutical formulations, which could provide better therapeutic response against iron deficiency anaemia.
\end{abstract}

Keywords: Ferrous Sulphate, Energy of Consciousness Healing Treatment, The Trivedi Effect ${ }^{\circledR}$, PXRD, Particle Size, DSC, TGA

\section{Introduction}

Ferrous sulphate or iron (II) sulphate traditionally also known as "green vitriol" or "copperas", which exists mostly in heptahydrate $\left(\mathrm{FeSO}_{4} \cdot 7 \mathrm{H}_{2} \mathrm{O}\right)$ form [1]. It is useful as the best source of iron for the supplement and reducing agent in 
the chemical reactions. The hydrated form of ferrous sulphate is very important and used as medicine for the treatment of iron deficiency anaemia [2]. It is also used for the manufacture of inks (iron gall ink), treating iron chlorosis in horticulture, lawn conditioner, gold refining, purification of water, wood panelling on houses, moss killer, and as a catalyst (Fenton's reagent) in chemical reactions [3-7].

Problems associated with the internal use of ferrous sulphate are stomach upset, constipation, black/dark-coloured stools, and staining of the teeth. It is in water $(29.51 \mathrm{~g} / 100 \mathrm{~mL}$ at $25^{\circ} \mathrm{C}$ ) and negligible in organic solvents [3, 8]. The complex physiological system of the human body and other dietary factors, only 1-2 mg of iron undergoes absorption through the gut enterocyte to the systemic circulation $[9,10]$. Iron deficiency is the most common nutritional disorder affecting more than $20 \%$ of the global population according to the World Health Organization (WHO). The solubility and bioavailability of the ferrous sulphate are the major concern for the effective therapeutic effect. The Trivedi Effect ${ }^{\mathbb{R}}-$ Consciousness Energy Healing Treatment could be an economical approach for modifying particle size/crystallite size, surface area and thermodynamic stability that would be helpful for better design for pharmaceutical/nutraceutical formulations $[11,12]$.

Biofield is referred as quantum energy matrix that surrounds the human body resulting from the continuous movement of the electrically charged components (ions, cells, etc.). The human body can release the electromagnetic waves in the form of bio-photons that surrounds the body. Biofield Energy Healers have the ability to harness the energy from the "Universal Energy Field" and can transmit into any living or non-living object(s). The process by which the objects receive the Biofield Energy Treatment from the Biofield Energy Healer(s) and respond in a useful way is called as Biofield Energy Healing [13-15]. Biofield based Energy Therapies are used worldwide to improve the quality of life. National Center of Complementary and Integrative Health (NCCIH) has recognized and accepted Biofield Energy Healing as a Complementary and Alternative Medicine (CAM) health care approach in addition to other therapies, medicines and practices such as yoga, meditation, deep breathing, Qi Gong, Tai Chi, chiropractic/osteopathic manipulation, Ayurvedic medicine, homeopathy, naturopathy, traditional Chinese herbs and medicines, aromatherapy, special diets, essential oils, massage, progressive relaxation, guided imagery, acupressure, acupuncture, healing touch, hypnotherapy, movement therapy, rolfing structural integration, pilates, mindfulness, Reiki, cranial sacral therapy and applied prayer, which are very common in religions like Hinduism, Christianity, Buddhism, etc. [16]. The Biofield Energy Healing Treatment (The Trivedi Effect ${ }^{\circledR}$ - Energy of Consciousness Healing Treatment) had been scientifically evaluated and reported with significant results in different scientific fields like materials science [17-21], agricultural science [22-25], cancer research [26, 27], microbiology [2830], pharmaceutical [12, 31, 32], genetics [33, 34], etc.

The physicochemical properties play an important role in bioavailability [36], and physicochemical and thermal properties are scientifically proved to be altered by The Trivedi Effect ${ }^{\circledR}$ - Energy of Consciousness Healing Treatment might be the possible mediation of neutrinos [37]. Thus, the current study was designed to evaluate the impact of The Trivedi Effect ${ }^{\circledR}$ - Energy of Consciousness Healing Treatment on the physicochemical and thermal properties of ferrous sulphate using powder X-ray diffraction (PXRD), particle size analysis (PSA), differential scanning calorimetry (DSC), and thermogravimetric analysis (TGA)/ Differential thermogravimetric analysis (DTG).

\section{Materials and Methods}

\subsection{Chemicals and Reagents}

Ferrous sulphate heptahydrate or iron (II) sulphate heptahydrate $(>99 \%)$ was purchased from Sigma-Aldrich, India. All other chemicals used during the experiments were of analytical grade available in India.

\subsection{Consciousness Energy Healing Treatment Strategies}

The test compound, ferrous sulphate was divided into two parts. One part of the test compound did not receive Biofield Energy Treatment and considered as untreated or control ferrous sulphate. The second part of the test compound received the Energy of Consciousness Healing Treatment by the renowned Biofield Energy Healer, Alice Branton (USA), and designated as the Biofield Energy Treated iron (II) sulphate. The Trivedi Effect ${ }^{\circledR}$ - Energy of Consciousness Healing Treatment was provided for 3 minutes through the Healer's Unique Energy Transmission process remotely to the test compound, which was kept under laboratory conditions. Similarly, the control compound was subjected to "sham" healer under the similar laboratory conditions. The sham healer did not have any knowledge about the Biofield Energy Treatment. After that, the Biofield Energy Treated and untreated samples were kept in similar sealed conditions and characterized using PXRD, PSA, DSC, and TGA techniques.

\subsection{Characterization}

\subsubsection{Powder X-ray Diffraction (PXRD) Analysis}

The PXRD analysis of ferrous sulphate was performed on a PANalytical X'Pert3 powder X-ray diffractometer, UK. Diffraction of the analyte was carried out using a copper line as the source of radiation at the X-ray of the wavelength of $0.154 \mathrm{~nm}$, running at $45 \mathrm{kV}$ voltage and $40 \mathrm{~mA}$ current with a scanning rate of $18.87^{\circ} /$ second over a $2 \theta$ range of $3-90^{\circ}$. The ratio of $\mathrm{K} \alpha-2$ and $\mathrm{K} \alpha-1$ in this instrument was 0.5 (k, equipment constant). The data was collected in the form of a chart of the Bragg angle ( $2 \theta)$ vs. intensity (counts per second), and a detailed table containing information on peak intensity counts, d value $(\AA)$, relative intensity (\%), full width half maximum $(\mathrm{FWHM})\left({ }^{\circ} 2 \theta\right)$, area $\left(\right.$ cts $\left.^{* \circ} 2 \theta\right)$ using X'Pert data collector and $X$ 'Pert high score plus processing software. The crystallite size $(\mathrm{G})$ was calculated from the Scherrer equation following the literature $[11,12,35-37]$. The crystallite size (G) 
was calculated by using the following equation 1 :

$$
\mathrm{G}=\mathrm{k} \lambda /(\mathrm{b} \operatorname{Cos} \theta)
$$

Where, $\mathrm{k}$ is the equipment constant $(0.5), \lambda$ is the $\mathrm{X}$-ray wavelength $(0.154 \mathrm{~nm})$; $\mathrm{b}$ in radians is the full-width at half of the peaks and $\theta$ the corresponding Bragg angle.

Percent change in crystallite size $(G)$ of ferrous sulphate was calculated using following equation 2 :

$\%$ change in crystallite size $=\frac{\left[\mathrm{G}_{\text {Treated }}-\mathrm{G}_{\text {Control }}\right]}{\mathrm{G}_{\text {Control }}} \times 100$

Where, $G_{\text {Control }}$ and $G_{\text {Treated }}$ are the crystallite size of the control and Biofield Energy Treated samples, respectively.

\subsubsection{Particle Size Analysis (PSA)}

The particle size analysis of ferrous sulphate was conducted on Malvern Mastersizer 3000, UK with a detection range between $0.01 \mu \mathrm{m}$ to $3000 \mu \mathrm{m}$ using wet method [11, 12, 35, 36]. The sample unit (Hydro MV) was filled with a dispersant medium (Light liquid paraffin oil) and operated the stirrer at $2500 \mathrm{rpm}$. Refractive index values for dispersant and samples were 0.0 and 1.47. The measurement was taken twice after reaching obscuration in between $10 \%$ and $20 \%$, and the average was taken of two measurements. Consequently, PSA analysis of ferrous sulphate was repeated for three times to obtain the average particle size distribution. $\mathrm{d}_{10} \mu \mathrm{m}, \mathrm{d}_{50} \mu \mathrm{m}$, and $\mathrm{d}_{90} \mu \mathrm{m}$ represent particle diameter corresponding to $10 \%, 50 \%$, and $90 \%$ of the cumulative distribution. $\mathrm{D}(4,3)$ represents the average mass-volume diameter and specific surface area (SSA, $\mathrm{m}^{2} / \mathrm{Kg}$ ). The calculations were done by using software Mastersizer V3.50.

The percent change in particle size (d) for at below $10 \%$ level $\left(\mathrm{d}_{10}\right), 50 \%$ level $\left(\mathrm{d}_{50}\right)$, and $90 \%$ level $\left(\mathrm{d}_{90}\right)$ was calculated using following equation 3 :

$$
\% \text { change in particle size }=\frac{\left[\mathrm{d}_{\text {Treated }}-\mathrm{d}_{\text {Control }}\right]}{\mathrm{d}_{\text {Control }}} \times 100
$$

Where, $d_{\text {Control }}$ and $d_{\text {Treated }}$ are the particle size $(\mu \mathrm{m})$ for at below $10 \%$ level $\left(\mathrm{d}_{10}\right), 50 \%$ level $\left(\mathrm{d}_{50}\right)$, and $90 \%$ level $\left(\mathrm{d}_{90}\right)$ of the control and Biofield Energy Treated samples, respectively.

Percent change in surface area (S) was calculated using following equation 4 :

$$
\% \text { change in surface area }=\frac{\left[\mathrm{S}_{\text {Treated }}-\mathrm{S}_{\text {Control }}\right]}{\mathrm{S}_{\text {Control }}} \times 100
$$

Where, $\mathrm{S}_{\text {Control }}$ and $\mathrm{S}_{\text {Treated }}$ are the surface area of the control and Biofield Energy Treated ferrous sulphate, respectively.

\subsubsection{Differential Scanning Calorimetry (DSC)}

The DSC thermogram of ferrous sulphate was performed in DSC Q2000 differential scanning calorimeter, USA under the dynamic nitrogen atmosphere with flow rate of 50 $\mathrm{mL} / \mathrm{min}$ with a sample mass of $\sim 2.5 \mathrm{mg}$ using aluminum pan at a heating rate of $10^{\circ} \mathrm{C} / \mathrm{min}$ from $30^{\circ} \mathrm{C}$ to $400^{\circ} \mathrm{C}[11,12$, $35,36]$. The $\%$ change in melting point $(\mathrm{T})$ was calculated using following equation 5 :

$$
\% \text { change in melting point }=\frac{\left[\mathrm{T}_{\text {Treated }}-\mathrm{T}_{\text {Control }}\right]}{\mathrm{T}_{\text {Control }}} \times 100
$$

Where, $\mathrm{T}_{\text {Control }}$ and $\mathrm{T}_{\text {Treated }}$ are the melting point of the control and treated samples, respectively.

Percent change in the latent heat of fusion $(\Delta \mathrm{H})$ was calculated using following equation 6 :

$$
\% \text { change in latent heat of fusion }=\frac{\left[\Delta \mathrm{H}_{\text {Treated }}-\Delta \mathrm{H}_{\text {Control }}\right]}{\Delta \mathrm{H}_{\text {Control }}} \times 100
$$

Where, $\Delta \mathrm{H}_{\text {Control }}$ and $\Delta \mathrm{H}_{\text {Treated }}$ are the latent heat of fusion of the control and treated ferrous sulphate, respectively.

\subsubsection{Thermal Gravimetric Analysis (TGA) / Differential Thermogravimetric Analysis (DTG)}

TGA/DTG thermograms of ferrous sulphate were obtained in a TGA Q500 themoanalyzer apparatus, USA under dynamic nitrogen atmosphere $(50 \mathrm{~mL} / \mathrm{min})$ using a platinum crucible at a heating rate of $10^{\circ} \mathrm{C} / \mathrm{min}$ from $25^{\circ} \mathrm{C}$ to $900^{\circ} \mathrm{C}$ with the recent literature $[11,12,35,36]$. The $\%$ change in weight loss $(\mathrm{W})$ was calculated using following equation 7 :

$$
\% \text { change in weight loss }=\frac{\left[\mathrm{w}_{\text {Treated }}-\mathrm{W}_{\text {Control }}\right]}{\mathrm{w}_{\text {Control }}} \times 100
$$

Where, $\mathrm{W}_{\text {Control }}$ and $\mathrm{W}_{\text {Treated }}$ are the weight loss of the control and Biofield Energy Treated ferrous sulphate, respectively.

The $\%$ change in maximum thermal degradation temperature $\left(\mathrm{T}_{\max }\right)(\mathrm{M})$ was calculated using following equation 7:

$$
\% \text { change in } \mathrm{T}_{\max }(\mathrm{M})=\frac{\left[\mathrm{M}_{\text {Treated }}-\mathrm{M}_{\text {Control }}\right]}{\mathrm{M}_{\text {Control }}} \times 100
$$

Where, $\mathrm{M}_{\text {Control }}$ and $\mathrm{M}_{\text {Treated }}$ are the $\mathrm{T}_{\max }$ values of the control and Biofield Energy Treated ferrous sulphate, respectively.

\section{Results and Discussion}

\subsection{Powder X-ray Diffraction (PXRD) Analysis}

PXRD data of the control and Biofield Energy Treated ferrous sulphate showed sharp and intense peaks in the diffractograms (Figure 1) indicating that both the samples are crystalline in nature. The crystallite size was calculated with the help of Scherrer equation [37]. PXRD data such as the Bragg angle $(2 \theta)$, relative intensity (\%), and crystallite size (G) for both the sample are presented in Table 1.

The highest intense peak (100\% relative intensity) in the control and Biofield Energy Treated samples was observed at

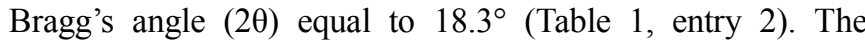


Bragg's angle $(2 \theta)$ of both the samples remained almost same, but the relative intensities of the peaks of the Biofield Energy Treated sample were found to be altered compared to the control sample. Thus, relative peak intensities of the Biofield Energy Treated ferrous sulphate were significantly altered in the range of $-26.74 \%$ to $421.23 \%$. However, the overall intensity of characteristic diffraction peaks improved after the Alice's Biofield Energy Treatment. The crystallite size values of the Biofield Energy Treated sample at $2 \theta$ equal to nearly $23.6^{\circ}, 27.9^{\circ}, 34.2^{\circ}$, and $36.9^{\circ}$ (Table 1 , entry 4 and 6-8) was significantly increased from $20.00 \%$ to $42.91 \%$ with respect to the control sample. On the contrary, the crystallite sizes of the control and Biofield Energy Treated samples at $2 \theta$ equal to nearly $18.3^{\circ}, 19.5^{\circ}$, and $27.4^{\circ}$ (Table 1 , entry 2,3 , and 5) were significantly decreased from $12.51 \%$ to $24.93 \%$ in the Biofield Energy Treated sample in comparison to the control sample. The crystallite size of the control and Biofield Energy Treated ferrous sulphate samples at position $2 \theta$ equal to nearly $16.2^{\circ}$ (Table 1, entry 1) remained unchanged. The overall crystallite size was significantly altered in the range from $-24.93 \%$ to $42.91 \%$ and average crystallite size significantly increased by $6.39 \%$ in the Biofield Energy Treated ferrous sulphate compared with the control sample. The changes in the XRD patterns such as crystallite size and relative intensities indicated the change of the crystal morphology as well as the proof of polymorphic transition [38-40]. As the crystallite size of the Alice's Biofield Energy Treated sample was significantly increased compared with the control sample, which might produce a new polymorphic form of ferrous sulphate. The alteration in crystal morphology, i.e. crystal pattern, size and even polymorphic form has the significant impact on the in vitro dissolution rate, which is directly related with the bioavailability of orally administered pharmaceutical and nutraceutical compounds [41, 42].
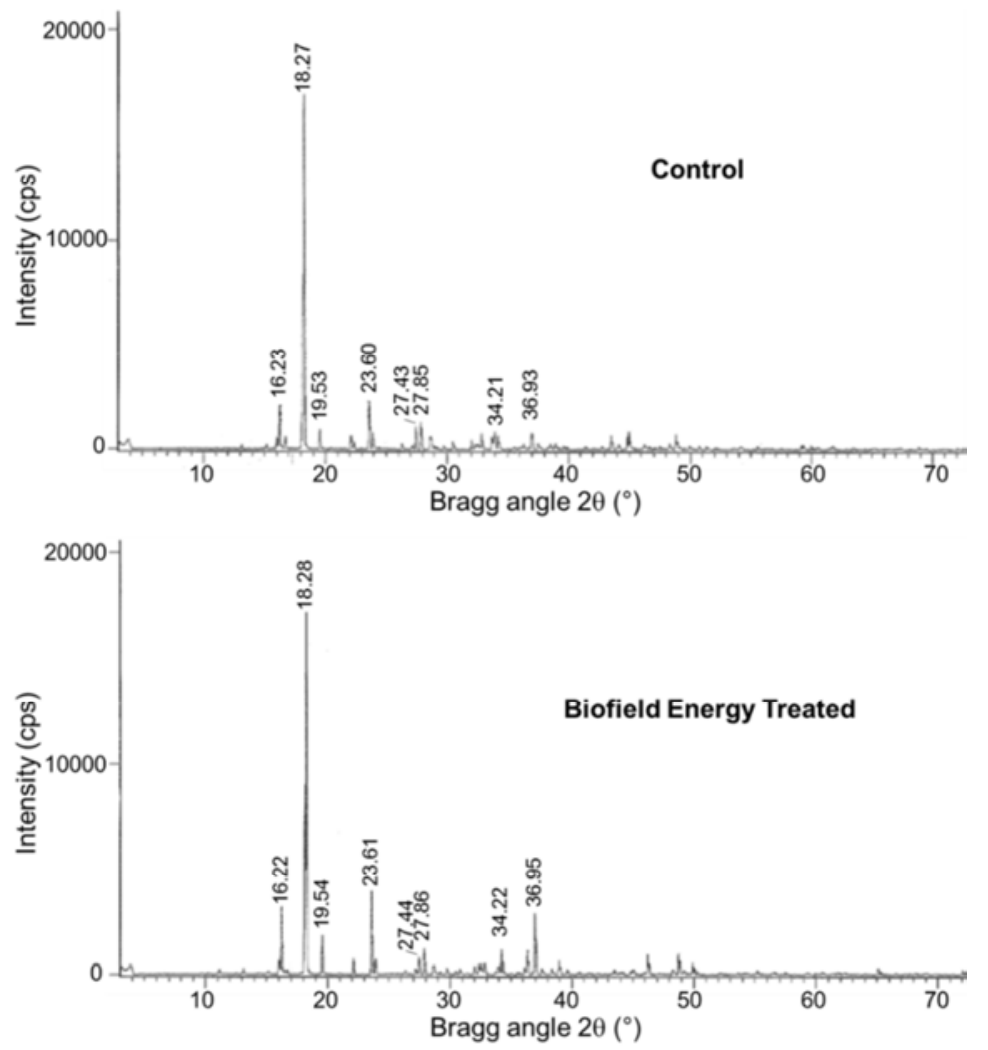

Figure 1. PXRD diffractograms of the control and Biofield Energy Treated ferrous sulphate.

Table 1. PXRD data for the control and Biofield Energy Treated ferrous sulphate.

\begin{tabular}{|c|c|c|c|c|c|c|c|}
\hline \multirow{2}{*}{ Entry No. } & \multirow{2}{*}{ Bragg angle $\left({ }^{\circ} 2 \theta\right)$} & \multicolumn{3}{|c|}{ Relative Intensity (\%) } & \multicolumn{3}{|c|}{ Crystallite size $(\mathbf{G}, \mathbf{n m})$} \\
\hline & & Control & Treated & $\%$ change $^{a}$ & Control & Treated & $\%$ change $^{b}$ \\
\hline 1 & 16.2 & 12.46 & 18.78 & 50.72 & 49.68 & 49.68 & 0.00 \\
\hline 2 & 18.3 & 100 & 100 & 0.00 & 58.05 & 43.58 & -24.93 \\
\hline 3 & 19.5 & 5.94 & 11.64 & 95.96 & 49.90 & 43.66 & -12.51 \\
\hline 4 & 23.6 & 12.84 & 22.26 & 73.36 & 35.16 & 50.25 & 42.91 \\
\hline 5 & 27.4 & 6.32 & 4.63 & -26.74 & 59.00 & 50.63 & -14.19 \\
\hline 6 & 27.9 & 7.4 & 6.84 & -7.57 & 59.05 & 70.87 & 20.00 \\
\hline 7 & 34.2 & 3.96 & 6.57 & 65.91 & 59.05 & 73.82 & 25.00 \\
\hline 8 & 36.9 & 3.25 & 16.94 & 421.23 & 59.51 & 74.39 & 25.01 \\
\hline 9 & Average & & & & 53.68 & 57.11 & 6.39 \\
\hline
\end{tabular}

${ }^{a}$ denotes the percentage change in the relative intensity of Biofield Energy Treated sample with respect to the control sample, ${ }^{b}$ denotes the percentage change in the crystallite size of Biofield Energy Treated sample with respect to the control sample. 


\subsection{Particle Size Analysis (PSA)}

The particle size and specific surface area of the control and Biofield Energy Treated ferrous sulphate were investigated and presented in Table 1 . It was observed that the particle size in the Biofield Energy Treated sample at $d_{10}$, $\mathrm{d}_{50}, \mathrm{~d}_{90}$ and $\mathrm{D}(4,3)$ values were significantly increased by $30.43 \%, \quad 35.94 \%, \quad 19.49 \%$, and $26.26 \%$, respectively compared to the control sample (Table 2). The surface area of the control and Biofield Energy Treated sample was found to be $44.93 \mathrm{~m}^{2} / \mathrm{kg}$ and $21.00 \mathrm{~m}^{2} / \mathrm{kg}$, respectively. The results indicated that the surface area of the Biofield Energy Treated ferrous sulphate was significantly decreased by $53.26 \%$ compared with the control sample.

Table 2. Particle size distribution of the control and Biofield Energy Treated ferrous sulphate.

\begin{tabular}{llllll}
\hline Test Item & $\mathbf{d}_{\mathbf{1 0}}(\boldsymbol{\mu m})$ & $\mathbf{d}_{\mathbf{5 0}}(\boldsymbol{\mu} \mathbf{m})$ & $\mathbf{d}_{\mathbf{9}}(\boldsymbol{\mu m})$ & $\mathbf{D}(\mathbf{4}, \mathbf{3})(\boldsymbol{\mu m})$ & $\mathbf{S S A}\left(\mathbf{m}^{\mathbf{2}} / \mathbf{K g}\right)$ \\
\hline Control & 115 & 320 & 790 & 396 & 44.93 \\
Biofield Energy Treated & 150 & 435 & 944 & 500 & 21.00 \\
Percent change* (\%) & 30.43 & 35.94 & 19.49 & 26.26 & -53.26 \\
\hline
\end{tabular}

$\mathrm{d}_{10}, \mathrm{~d}_{50}$, and $\mathrm{d}_{90}$ : particle diameter corresponding to $10 \%, 50 \%$, and $90 \%$ of the cumulative distribution, $\mathrm{D}(4,3)$ : the average mass-volume diameter, and SSA: the specific surface area, "denotes the percentage change in the Particle size distribution of the Biofield Energy Treated sample with respect to the control sample.

The particle size and surface area of a pharmaceutical or nutraceutical compound play a vital role in the solubility, dissolution, absorption, and bioavailability [42, 43-45]. The introduction of the Biofield Energy Treatment might transform the fine particles into larger particles. The increased the particle size enhanced the flowability, shape, and appearance of the compound $[45,46]$. It is assumed that The Trivedi Effect $^{\circledR}$ - Energy of Consciousness Healing Treatment might improve the powder flowability of ferrous sulphate.

\subsection{Differential Scanning Calorimetry (DSC) Analysis}

Scientific literature nicely described the dehydration behavior of a hydrated iron salt, ferrous sulphate heptahydrate $\left(\mathrm{FeSO}_{4} \cdot 7 \mathrm{H}_{2} \mathrm{O}\right)$ by using DSC and TGA techniques [47, 48]. Wang et al mentioned 3 peaks in the DSC curve at a heating rate of $10^{\circ} \mathrm{C}$ under nitrogen atmosphere. $1^{\text {st }}$ peak at temperature below $100^{\circ} \mathrm{C}, 2^{\text {nd }}$ peak at 85 to $149^{\circ} \mathrm{C}$, and $3^{\text {rd }}$ peak at 247 to $342^{\circ} \mathrm{C}$ were due to the dehydration of 7 water molecules from $\mathrm{FeSO}_{4} \cdot 7 \mathrm{H}_{2} \mathrm{O}$ to $\mathrm{FeSO}_{4} \bullet 4 \mathrm{H}_{2} \mathrm{O}, \mathrm{FeSO}_{4} \bullet 4 \mathrm{H}_{2} \mathrm{O}$ to $\mathrm{FeSO}_{4} \bullet \mathrm{H}_{2} \mathrm{O}$, and $\mathrm{FeSO}_{4} \bullet \mathrm{H}_{2} \mathrm{O}$ to $\mathrm{FeSO}_{4}$, respectively. They also concluded that accurate thermal data from the TGA/DSC dehydration experiments depends on various factors like proper selection of the heating rate, particle size, open or closed pan, etc. [47].

The DSC thermograms of the control ferrous sulphate heptahydrate (Figure 2) exhibited the presence of the four endothermic peaks at $72.73,100.20,114.73,279.47^{\circ} \mathrm{C}$. The $1^{\text {st }}$ sharp endothermic peak at $72.73^{\circ} \mathrm{C}$ was the melting point of ferrous sulphate heptahydrate. Consequently, the melting temperature of Biofield Energy Treated ferrous sulphate heptahydrate was significantly increased by $1.61 \%$ with a significant enhancement of the latent heat of fusion $(\Delta \mathrm{H})$ by $9.98 \%$ (Table 3 ) compared with the control sample. The $2^{\text {nd }}$ broad endothermic peak at $100.20^{\circ} \mathrm{C}$ might be due to the dehydration of 2 molecules of water from $\mathrm{FeSO}_{4} \cdot 6 \mathrm{H}_{2} \mathrm{O}$ to $\mathrm{FeSO}_{4} \cdot 4 \mathrm{H}_{2} \mathrm{O}$. This endotherm temperature in the Biofield energy Treated sample was reduced by $5.71 \%$ with a significant reduction in $\Delta \mathrm{H}$ compared with the control sample. The melting temperature of the $3^{\text {rd }}$ sharp endothermic peak, which was due to the removal of 3 molecules of water from $\mathrm{FeSO}_{4} \bullet 4 \mathrm{H}_{2} \mathrm{O}$ to $\mathrm{FeSO}_{4} \cdot \mathrm{H}_{2} \mathrm{O}$ was increased by $1.04 \%$ with a significant increase of $\Delta \mathrm{H}$ by $5.32 \%$ compared with the control sample. Finally, a broad endothermic peaks at $279.47^{\circ} \mathrm{C}$ was observed in the control sample due to the dehydration from ferrous sulphate monohydrate to anhydrous $\mathrm{FeSO}_{4}$. This melting temperature was reduced by $1.57 \%$ in the Biofield Energy Treated sample with a significant decrease by $6.10 \%$ in $\Delta \mathrm{H}$ compared with the control sample (Table 3). The total latent heat of fusion to transition from $\mathrm{FeSO}_{4} \cdot 7 \mathrm{H}_{2} \mathrm{O}$ to $\mathrm{FeSO}_{4}$ was decreased by $0.44 \%$ in the Biofield Energy Treated sample $(1118.00 \mathrm{~J} / \mathrm{g})$ compared with the control sample $(1122.90 \mathrm{~J} / \mathrm{g})$. The DSC analysis suggested that the thermal stability of the Biofield Energy Treated ferrous sulphate heptahydrate was increased compared with the control sample.

Table 3. The melting point $\left({ }^{\circ} \mathrm{C}\right)$ and latent heat of fusion $(\mathrm{J} / \mathrm{g})$ values for both control and Biofield Energy Treated samples of ferrous sulphate.

\begin{tabular}{|c|c|c|c|c|c|c|c|c|}
\hline \multirow{2}{*}{ Sample } & \multicolumn{4}{|c|}{ Temperature $\left({ }^{\circ} \mathrm{C}\right)$} & \multicolumn{4}{|l|}{$\Delta \mathbf{H}(\mathbf{J} / \mathbf{g})$} \\
\hline & $1^{\text {st }}$ Peak & $2^{\text {nd }}$ Peak & $3^{\text {rd }}$ Peak & $4^{\text {th }}$ Peak & $1^{\text {st }}$ Peak & 2nd Peak & $3^{\text {rd }}$ Peak & $4^{\text {th }}$ Peak \\
\hline Control Sample & 72.73 & 100.20 & 114.73 & 279.47 & 114.20 & 184.40 & 547.20 & 277.10 \\
\hline Biofield Energy Treated & 73.90 & 94.48 & 115.92 & 275.07 & 125.60 & 155.90 & 576.30 & 260.20 \\
\hline$\%$ Change $^{*}$ & 1.61 & -5.71 & 1.04 & -1.57 & 9.98 & -15.46 & 5.32 & -6.10 \\
\hline
\end{tabular}

$\Delta \mathrm{H}$ : Latent heat, ${ }^{*}$ denotes the percentage change of the Biofield Energy Treated sample with respect to the control sample. 

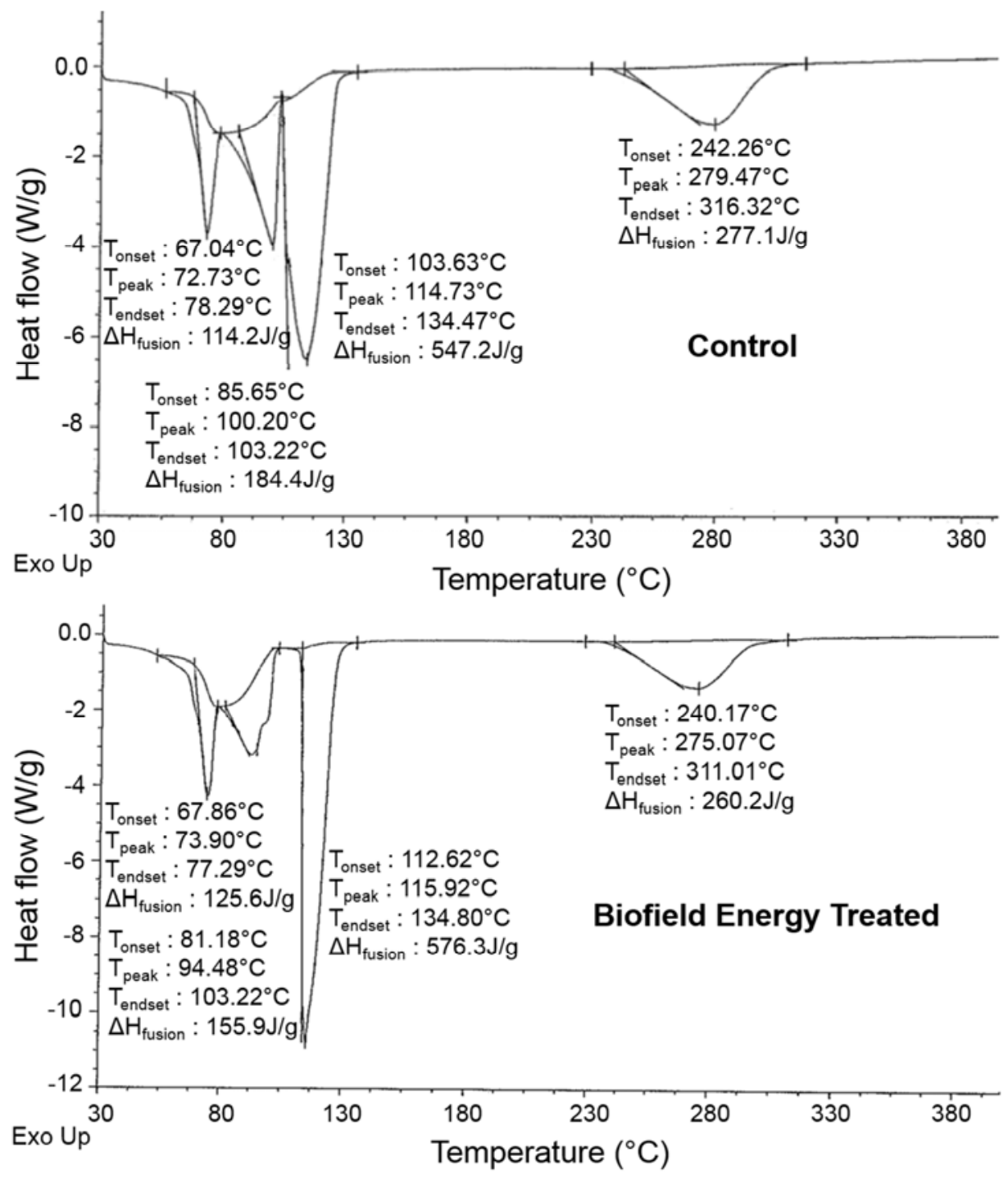

Figure 2. DSC thermograms of the control and Biofield Energy Treated ferrous sulphate samples.

\subsection{Thermal Gravimetric Analysis (TGA) / Differential Thermogravimetric Analysis (DTG)}

The TGA thermogram pattern of the control sample (Figure 3) was matched with the literature. The first weight loss occurs between 70 and $90^{\circ} \mathrm{C}$ due to the loss of 3 water molecules from $\mathrm{FeSO}_{4} \cdot 7 \mathrm{H}_{2} \mathrm{O}$. The second dehydration step with the loss of 3 water molecules from $\mathrm{FeSO}_{4} \bullet 4 \mathrm{H}_{2} \mathrm{O}$ is responsible for the mass loss between 140 and $200^{\circ} \mathrm{C}$. Consequently, the third weight loss is found between 270 and $350^{\circ} \mathrm{C}$ due to the dehydration of $\mathrm{FeSO}_{4} \cdot \mathrm{H}_{2} \mathrm{O}$. Final major weight loss between 400 and $830^{\circ} \mathrm{C}$ occurs due to the oxidation and dehydration of the other part of monohydrate, sulphate decomposition. The major weight loss occurred in the first $(38.30 \%)$ and fourth $(28.30 \%)$ reactions $[47,48]$.
Here, the TGA thermograms of the control and Biofield Energy Treated samples (Figure 3) exhibited four steps of thermal degradation, which was matched with the literature $[47,48]$. The \% weight loss in the Biofield Energy Treated ferrous sulphate was significantly increased by $15.67 \%$ and $7.01 \%$ in the $1^{\text {st }}$ and $3^{\text {rd }}$ steps of degradation, respectively compared with the control sample. Consequently, the \% weight loss in the $2^{\text {nd }}$ and $4^{\text {th }}$ steps of degradation was reduced by $5.51 \%$ and $1.63 \%$, respectively, compared with the control sample (Table 4). The total \% weight loss of the control and Biofield Energy Treated ferrous sulphate were $71.06 \%$ and $71.5 \%$, respectively. The total weight loss in the Biofield Energy Treated ferrous sulphate was increased by $0.62 \%$ compared with the control sample. 

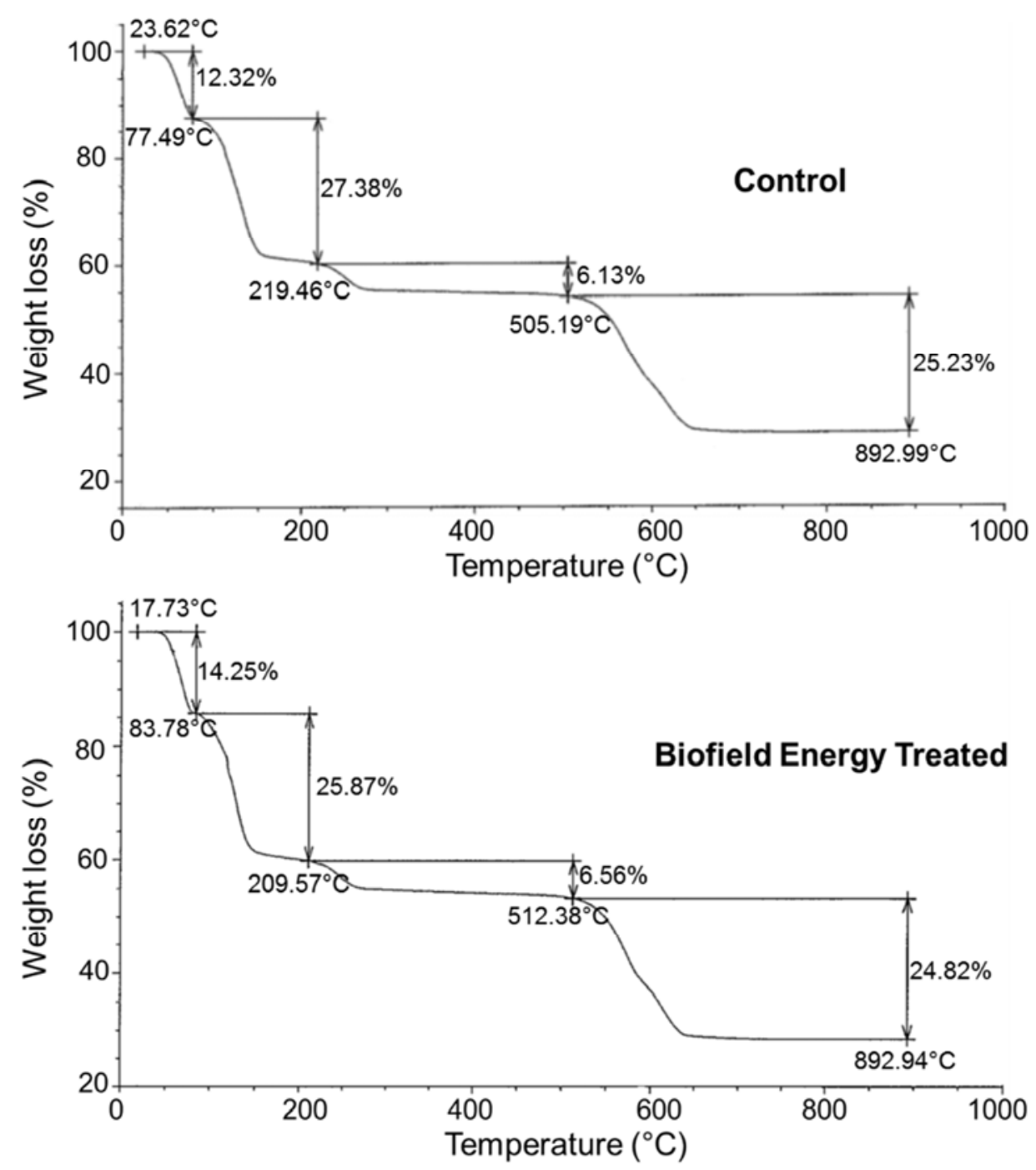

Figure 3. TGA thermograms of the control and Biofield Energy Treated ferrous sulphate.

Table 4. Thermal degradation steps of the control and Biofield Energy Treated samples of ferrous sulphate.

\begin{tabular}{llll}
\hline \multirow{2}{*}{ Step } & \multicolumn{2}{l}{ \%Weight Loss } & \multirow{2}{*}{ \%Change* } \\
\cline { 2 - 3 } & Control & Treated & \\
\hline $1^{\text {st }}$ step of degradation & 12.32 & 14.25 & 15.67 \\
$2^{\text {nd }}$ step of degradation & 27.38 & 25.87 & -5.51 \\
$3^{\text {rd }}$ step of degradation & 6.13 & 6.56 & 7.01 \\
$4^{\text {th }}$ step of degradation & 25.23 & 24.82 & -1.63 \\
Total weight loss & 71.06 & 71.50 & 0.62 \\
\hline
\end{tabular}

*denotes the percentage change of the Biofield Energy Treated sample with respect to the control sample.

The DTG thermograms of the control sample disclosed four peaks $\mathrm{P}_{1}, \mathrm{P}_{2}, \mathrm{P}_{3}$, and $\mathrm{P}_{4}$ with maximum thermal decomposition temperature $\left(\mathrm{T}_{\max }\right)$ of $63.00,133.42,251.59$, and $570.93^{\circ} \mathrm{C}$, respectively (Figure 4 and Table 5). Similarly, the DTG thermograms of the Biofield Energy Treated sample disclosed four peaks $\mathrm{P}_{1}, \mathrm{P}_{2}, \mathrm{P}_{3}$, and $\mathrm{P}_{4}$ with $\mathrm{T}_{\max }$ of $66.66,129.98$, 245.60 , and $572.44^{\circ} \mathrm{C}$, respectively (Figure 4 and Table 5). The analysis indicated that the $\mathrm{T}_{\max }$ of the Biofield Energy Treated ferrous sulphate was increased by $5.81 \%$ and $0.26 \%$ in the $1^{\text {st }}$ and $4^{\text {th }}$ peak respectively, but the $\mathrm{T}_{\max }$ of $2^{\text {nd }}$ and $3^{\text {rd }}$ peaks were decreased by $2.58 \%$ and $2.38 \%$, respectively compared to the control sample. As per the literature, with alteration of the particle size changed the thermal stability of a sample [49]. Overall, TGA/DTG revealed that the thermal stability of the Biofield Energy Treated ferrous sulphate was altered as compared with the control sample.

Table 5. The maximum thermal degradation temperature $\left(T_{\max }\right)$ of the control and Biofield Energy Treated samples of ferrous sulphate.

\begin{tabular}{lllll}
\hline \multirow{2}{*}{ Description } & \multicolumn{4}{l}{ Maximum thermal degradation temperature $\left({ }^{\circ} \mathbf{C}\right)$} \\
\cline { 2 - 5 } & $\mathbf{P}_{\mathbf{1}}\left({ }^{\circ} \mathbf{C}\right)$ & $\mathbf{P}_{\mathbf{2}}\left({ }^{\circ} \mathbf{C}\right)$ & $\mathbf{P}_{\mathbf{3}}\left({ }^{\circ} \mathbf{C}\right)$ & $\mathbf{P}_{\mathbf{4}}\left({ }^{\circ} \mathbf{C}\right)$ \\
\hline Control Sample & 63.00 & 133.42 & 251.59 & 570.93 \\
Biofield Energy Treated & 66.66 & 129.98 & 245.6 & 572.44 \\
\%Change* & 5.81 & -2.58 & -2.38 & 0.26 \\
\hline
\end{tabular}

$\mathrm{P}_{1}, \mathrm{P}_{2}, \mathrm{P}_{3}$, and $\mathrm{P}_{4}$ : peak 1, 2, 3, and 4. ${ }^{*}$ denotes the percentage change of the Biofield Energy Treated sample with respect to the control sample. 

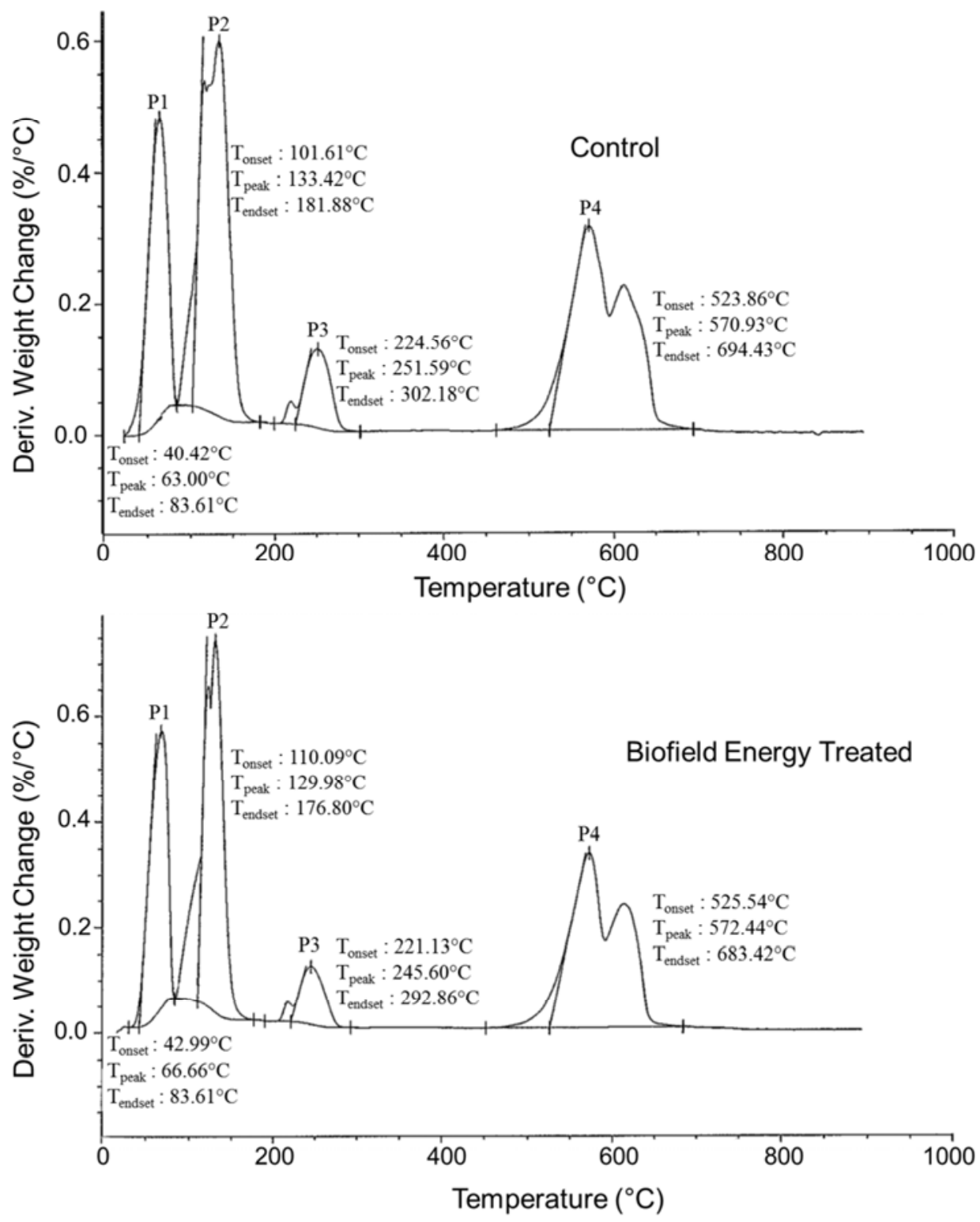

Figure 4. DTG thermograms of the control and Biofield Energy Treated ferrous sulphate.

\section{Conclusions}

The Trivedi Effect ${ }^{\circledR}$ - Energy of Consciousness Healing Treatment has shown the significant impact on the relative intensity and crystallite size of the diffraction peaks, particle size, surface area, and thermal properties of ferrous sulphate. The PXRD diffractograms of both the sample showed sharp and intense peaks indicated that the ferrous sulphate was crystalline in nature. The relative intensities and crystallite size of the characteristic diffraction peaks in the Biofield Energy Treated sample were significantly altered in the range from $26.74 \%$ to $421.23 \%$ and from $-24.93 \%$ to $42.91 \%$, respectively compared with the control sample. The average crystallite size of the Biofield Energy Treated sample was significantly increased by $6.39 \%$ compared with the control sample. The particle size values at $\mathrm{d}_{10}, \mathrm{~d}_{50}, \mathrm{~d}_{90}$ and $\mathrm{D}(4,3)$ values were significantly increased by $30.43 \%, 35.94 \%, 19.49 \%$, and $26.26 \%$, respectively and the surface area was significantly decreased by $53.26 \%$ compared with the control sample. The melting temperature of the Biofield Energy Treated sample in the $1^{\text {st }}$ and $3^{\text {rd }}$ peaks was increased by $1.61 \%$ and $1.04 \%$ respectively; whereas decreased by $5.71 \%$ and $1.04 \%$ in the $2^{\text {nd }}$ and $4^{\text {th }}$ peaks, respectively compared with the control sample. Similarly, the latent heat of fusion $(\Delta \mathrm{H})$ of $1^{\text {st }}$ and $3^{\text {rd }}$ peaks in the Biofield Energy Treated ferrous sulphate was significantly increased by $9.98 \%$ and $5.32 \%$ respectively; whereas $\Delta \mathrm{H}$ of the $2^{\text {nd }}$ and $4^{\text {th }}$ peak was decreased by $15.46 \%$ and $6.10 \%$, respectively compared with the control sample. The TGA thermograms of both the samples exhibited four steps of thermal degradation. The total weight loss in the Biofield Energy Treated ferrous sulphate was enhanced by $0.62 \%$ compared with the control sample. The maximum thermal decomposition temperature $\left(\mathrm{T}_{\max }\right)$ of the Biofield Energy Treated ferrous sulphate was increased by $5.81 \%$ and $0.26 \%$ in the $1^{\text {st }}$ and $4^{\text {th }}$ peak respectively, but the $\mathrm{T}_{\max }$ of $2^{\text {nd }}$ and $3^{\text {rd }}$ peaks were reduced by $2.58 \%$ and $2.38 \%$, respectively 
compared to the control sample. Overall, DSC and TGA/DTG of the treated sample showed that the thermodynamic stability was changed compared with the control sample. These results suggested that The Trivedi Effect ${ }^{\circledR}$ - Consciousness Energy Healing Treatment might lead to the production of a polymorphic form of ferrous sulphate, which would provide better powder flowability and appearance having altered thermal stability compared with the control sample. The Alice's Biofield Energy Treated ferrous sulphate would be beneficial to design better nutraceutical and/or pharmaceutical formulations which might offer better therapeutic response against iron deficiency anemia.

\section{Acknowledgements}

The authors are grateful to GVK Biosciences Pvt. Ltd., Trivedi Science, Trivedi Global, Inc., Trivedi Testimonials, and Trivedi Master Wellness for their assistance and support during this work.

\section{References}

[1] Reddy SN, Rao PS, Ravikumar RV, Reddy BJ, Reddy YP (2001) Spectral investigations on melanterite mineral from France. Spectrochim Acta A Mol Biomol Spectrosc 57: 1283.

[2] Lide, David R., ed. (2009) CRC Handbook of Chemistry and Physics $\left(90^{\text {th }}\right.$ ed.). Boca Raton, Florida: CRC Press.

[3] https://en.wikipedia.org/wiki/Iron (II)_sulfate.

[4] Jančovičová V, Čeppan M, Havlínová B, M. RehákováZ. Jakubíková (2007) Interactions in iron gall inks Chemical Papers 61: 391-397.

[5] Koenig R, Kuhns M (2010) Control of iron chlorosis in ornamental and crop plants. Utah State University, Salt Lake City, August.

[6] Hayyan M, Hashim MA, AlNashef IM (2016) Superoxide ion: generation and chemical implications. Chem Rev 116: 30293085 .

[7] Fenton HJH (1894) Oxidation of tartaric acid in presence of iron. J Chem Soc 65: 899-911.

[8] Bothara KG (2007) Inorganic Pharmaceutical Chemistry. $9^{\text {th }}$ Edition, Nirali Prakashan, Pune, India.

[9] Zariwala MG, Somavarapu S, Farnaud S, Renshaw D (2013) Comparison study of oral iron preparations using a human intestinal model. Sci Pharm. 81: 1123-1139.

[10] Zimmermann MB, Hurrell RF (2007) Nutritional iron deficiency. Lancet. 370: 511-520.

[11] Trivedi MK, Branton A, Trivedi D, Nayak G, Lee AC, Hancharuk A, Sand CM, Schnitzer DJ, Thanasi R, Meagher EM, Pyka FA, Gerber GR, Stromsnas JC, Shapiro JM, Streicher LN, Hachfeld LM, Hornung MC, Rowe PM, Henderson SJ, Benson SM, Holmlund ST, Salters SP, Panda P, Jana $S$ (2017) A comprehensive analytical evaluation of the Trivedi Effect ${ }^{\circledR}$ - Energy of Consciousness Healing Treatment on the physical, structural, and thermal properties of zinc chloride. American Journal of Applied Chemistry 5: 7-18.
[12] Trivedi MK, Branton A, Trivedi D, Nayak G, Plikerd WD, Surguy PL, Kock RJ, Piedad RB, Callas RP, Ansari SA, Barrett SL, Friedman S, Christie SL, Chen Liu S-M, Starling SE, Jones S, Allen SM, Wasmus SK, Benczik TA, Slade TC, Orban T, Vannes VL, Schlosser VM, Albino YSY, Panda P, Sethi KK, Jana S (2017). A systematic study of the biofield energy healing treatment on physicochemical, thermal, structural, and behavioral properties of magnesium gluconate. International Journal of Bioorganic Chemistry. 2: 135-145.

[13] Rubik B (2002) The biofield hypothesis: Its biophysical basis and role in medicine. J Altern Complement Med 8: 703-717.

[14] Rivera-Ruiz M, Cajavilca C, Varon J (2008) Einthoven's string galvanometer: The first electrocardiograph. Tex Heart Inst J 35: 174-178.

[15] Nemeth L (2008) Energy and biofield therapies in practice. Beginnings 28: 4-5.

[16] Koithan M (2009) Introducing complementary and alternative therapies. J Nurse Pract 5: 18-20.

[17] Trivedi MK, Nayak G, Patil S, Tallapragada RM, Latiyal O, Jana S (2015) Impact of biofield treatment on atomic and structural characteristics of barium titanate powder. Ind Eng Manage 4: 166.

[18] Trivedi MK, Tallapragada RM, Branton A, Trivedi D, Nayak G, Jana S (2015) Characterization of physical and structural properties of aluminum carbide powder: Impact of biofield treatment. J Aeronaut Aerospace Eng 4: 142.

[19] Trivedi MK, Patil S, Nayak G, Jana S, Latiyal O (2015) Influence of biofield treatment on physical, structural and spectral properties of boron nitride. J Material Sci Eng 4: 181.

[20] Trivedi MK, Nayak G, Patil S, Tallapragada RM, Latiyal O, Jana S (2015) Characterization of physical and structural properties of brass powder after biofield treatment. J Powder Metall Min 4: 134.

[21] Trivedi MK, Tallapragada RM, Branton A, Trivedi D, Nayak G, Latiyal O, Jana S (2015) Evaluation of physical and structural properties of biofield energy treated barium calcium tungsten oxide. Advances in Materials 4: 95-100.

[22] Trivedi MK, Branton A, Trivedi D, Nayak G, Mondal SC, Jana S (2015) Morphological characterization, quality, yield and DNA fingerprinting of biofield energy treated alphonso mango (Mangifera indica L.). Journal of Food and Nutrition Sciences 3: 245-250.

[23] Trivedi MK, Branton A, Trivedi D, Nayak G, Gangwar M, Jana S (2015) Agronomic characteristics, growth analysis, and yield response of biofield treated mustard, cowpea, horse gram, and groundnuts. International Journal of Genetics and Genomics 3: 74-80.

[24] Trivedi MK, Branton A, Trivedi D, Nayak G, Mondal SC, Jana S (2015) Evaluation of plant growth, yield and yield attributes of biofield energy treated mustard (Brassica juncea) and chick pea (Cicer arietinum) seeds. Agriculture, Forestry and Fisheries 4: 291-295.

[25] Trivedi MK, Branton A, Trivedi D, Nayak G, Mondal SC, Jana S (2015) Evaluation of plant growth regulator, immunity and DNA fingerprinting of biofield energy treated mustard seeds (Brassica juncea). Agriculture, Forestry and Fisheries 4: 269-274. 
[26] Trivedi MK, Patil S, Shettigar H, Mondal SC, Jana S (2015) The potential impact of biofield treatment on human brain tumor cells: A time-lapse video microscopy. J Integr Oncol 4: 141.

[27] Trivedi MK, Patil S, Shettigar H, Gangwar M, Jana S (2015) In vitro evaluation of biofield treatment on cancer biomarkers involved in endometrial and prostate cancer cell lines. J Cancer Sci Ther 7: 253-257.

[28] Trivedi MK, Branton A, Trivedi D, Nayak G, Mondal SC, Jana S (2015) Antimicrobial sensitivity, biochemical characteristics and biotyping of Staphylococcus saprophyticus An impact of biofield energy treatment. J Women's Health Care 4: 271.

[29] Trivedi MK, Patil S, Shettigar H, Mondal SC, Jana S (2015) In vitro evaluation of biofield treatment on Enterobacter cloacae: Impact on antimicrobial susceptibility and biotype. $\mathrm{J}$ Bacteriol Parasitol 6: 241.

[30] Trivedi MK, Patil S, Shettigar H, Mondal SC, Jana S (2015) Evaluation of biofield modality on viral load of Hepatitis B and C Viruses. J Antivir Antiretrovir 7: 083-088.

[31] Trivedi MK, Patil S, Shettigar H, Bairwa K, Jana S (2015) Spectroscopic characterization of biofield treated metronidazole and tinidazole. Med Chem 5: 340-344.

[32] Trivedi MK, Patil S, Shettigar H, Bairwa K, Jana S (2015) Effect of biofield treatment on spectral properties of paracetamol and piroxicam. Chem Sci J 6: 98.

[33] Trivedi MK, Branton A, Trivedi D, Nayak G, Mondal SC, Jana S (2015) Evaluation of antibiogram, genotype and phylogenetic analysis of biofield treated Nocardia otitidis. Biol Syst Open Access 4: 143.

[34] Trivedi MK, Branton A, Trivedi D, Nayak G, Charan S, Jana S (2015) Phenotyping and 16S rDNA analysis after biofield treatment on Citrobacter braakii: A urinary pathogen. J Clin Med Genom 3: 129.

[35] Trivedi MK, Branton A, Trivedi D, Nayak G, Lee AC, Hancharuk A, Sand CM, Schnitzer DJ, Thanasi R, Meagher EM, Pyka FA, Gerber GR, Stromsnas JC, Shapiro JM, Streicher LN, Hachfeld LM, Hornung MC, Rowe PM, Henderson SJ, Benson SM, Holmlund ST, Salters SP, Panda P, Jana S (2017) investigation of physicochemical, spectral, and thermal properties of sodium selenate treated with the Energy of Consciousness (The Trivedi Effect ${ }^{\mathbb{B}}$ ). American Journal of Life Sciences 5: 27-37.

[36] Trivedi MK, Branton A, Trivedi D, Nayak G, Nykvist CD, Lavelle C, Przybylski DP, Vincent DH, Felger D, Konersman DJ, Feeney EA, Prague JA, Starodub JL, Rasdan K, Strassman KM, Soboleff L, Mayne MA, Keesee MM, Pillai PN, Ansley PC, Schmitz RD, Sodomora SM, Sethi KK, Panda P, Jana S (2017) Evaluation of the Trivedi Effect ${ }^{\mathbb{B}}-$ Energy of
Consciousness Energy Healing Treatment on the physical, spectral, and thermal properties of zinc chloride. American Journal of Life Sciences. 5: 11-20.

[37] Langford JI, Wilson AJC (1978) Scherrer after sixty years: A survey and some new results in the determination of crystallite size. J Appl Cryst 11: 102-113.

[38] Inoue M, Hirasawa I (2013) The relationship between crystal morphology and XRD peak intensity on $\mathrm{CaSO}_{4} 2 \mathrm{H}_{2} \mathrm{O}$. J Crystal Growth 380: 169-175.

[39] Raza K, Kumar P, Ratan S, Malik R, Arora S (2014) Polymorphism: The phenomenon affecting the performance of drugs. SOJ Pharm Pharm Sci 1: 10.

[40] Brittain HG (2009) Polymorphism in pharmaceutical solids in Drugs and Pharmaceutical Sciences, volume 192, $2^{\text {nd }}$ Edn, Informa Healthcare USA, Inc., New York.

[41] Trivedi MK, Sethi KK, Panda P, Jana S (2017) Physicochemical, thermal and spectroscopic characterization of sodium selenate using XRD, PSD, DSC, TGA/DTG, UVvis, and FT-IR. Marmara Pharmaceutical Journal 21/2: 311318 .

[42] Zhao Z, Xie M, Li Y, Chen A, Li G, Zhang J, Hu H, Wang X, Li S (2015) Formation of curcumin nanoparticles via solutionenhanced dispersion by supercritical $\mathrm{CO}_{2}$. Int J Nanomedicine 10: $3171-3181$.

[43] Chereson R (2009) Bioavailability, bioequivalence, and drug selection. In: Makoid CM, Vuchetich PJ, Banakar UV (Eds) Basic pharmacokinetics $\left(1^{\text {st }}\right.$ Edn) Pharmaceutical Press, London.

[44] Khadka P, Ro J, Kim H, Kim I, Kim JT, Kim H, Cho JM, Yun G, Lee J (2014) Pharmaceutical particle technologies: An approach to improve drug solubility, dissolution and bioavailability. Asian J Pharm Sci 9: 304-316.

[45] Buckton G, Beezer AE (1992) The relationship between particle size and solubility. Int J Pharmaceutics 82: R7-R10.

[46] Mosharrof M, Nyström C (1995) The effect of particle size and shape on the surface specific dissolution rate of microsized practically insoluble drugs. Int J Pharm 122: 35-47.

[47] Wang T, Debelak KA, Roth JA (2007) Dehydration of iron (II) sulfate heptahydrate. Thermochimica Acta 462: 89-93.

[48] Földvári M (2011) Handbook of thermogravimetric system of minerals and its use in geological practice. Vol. 213, Occasional Papers of the Geological Institute of Hungary, Budapest.

[49] Zhang M, Efremov MY, Schiettekatte F, Olson EA, Kwan AT, Lai SL, Wisleder T, Greene JE, Allen LH (2000) Sizedependent melting point depression of nanostructures: Nanocalorimetric measurements. Phys Rev B 62: 10548. 